\title{
Innovative Transformation of Manufacturing Vacuum Equipment at Mechanical Engineering Enterprises
}

\author{
Nurbakhyt N. Nurmukhametov ${ }^{1 *}$, Altyn B. Amerkhanova ${ }^{1}$, Karlygash T. Auyezova $^{1}$ \\ ${ }^{1}$ NJSC L.N. Gumilyov Eurasian National University, 2 K. Satpayev Str., 010008, Nur-Sultan, \\ Kazakhstan
}

\begin{abstract}
The purpose of the article investigates introducing new products processes at mechanical engineering enterprises based on the innovative transformation of vacuum production equipment. In the context of global competition activities of large Kazakhstan's enterprises are characterized by an insufficient level of innovation activity. Building the infrastructure and production potential is the main in effective management production activities of engineering enterprises. The heads of enterprises are primarily concerned by the situation since innovation development has a significant impact on competitiveness, industrial enterprises' export potential and could ensure the balance of the economic sectors. Authors are interested in conducting an economic analysis of the business entities' activities, which aimed at efficiency increasing and quality of work in all links of industrial production. Authors suppose that practice requires the development of complex measures related to the peculiarities of investigating scientific and practical problems of increasing the production activities efficiency in the economy. In the authors' opinion, the investment project can become the basis for effective innovation implementation at mechanical engineering enterprises. They analyzed the financial activity of the enterprise and developed measures to reduce the production costs and products sales on the example of JSC «Vostokmashzavod». The result of the study is an investment project that arouses interest from the subjects of the machine-building industry from the point of view of the practical applicability of projects to reduce production costs, and the efficiency of their management.
\end{abstract}

Keywords: cost management, innovation, vacuum equipment, industrial enterprises, mechanical engineering, investment project

For citation: Nurmukhametov, N.N., Amerkhanova, A.B., \& Auyezova K.T. (2021). Innovative Transformation of Manufacturing Vacuum Equipment at Mechanical Engineering Enterprises. Economics: the Strategy and Practice, 16(4), 18-33, https://doi.org/10.51176/1997-9967-2021-4 -18-33

* Corresponding author: Nurmukhametov N.N. - candidate economic sciences, associate professor NJSC L.N. Gumilyov Eurasian National University, 2 K. Satpayev Str., 010005, Nur-Sultan, Kazakhstan, 87056314503, e-mail: nyrbahit73@mail.ru

Conflict of interests: the authors declare that there is no conflict of interest.

Financial support: private financing within the framework of the investment project implementation at mechanical engineering enterprises.

The article received: 01.12 .2021

The article approved for publication: 24.12. 2021

Date of publication: 30.12 .2021 


\title{
Машина жасау кәсіпорындарындағы өндірістің вакуумдық жабдықтарының инновациялық трансформациясы
}

\author{
Нұрмұхаметов Н.H. ${ }^{\text {*, }}$, Амерханова А.Б. ${ }^{1}$, Ауезова К.Т. ${ }^{1}$ \\ ${ }^{1}$ Л.Н..Гумилев атындавы Еуразия ұлттық университеті, Қ.Сәтбаева көш., 2, 010005, Нұр- \\ Сұлтан, Қазақ̧стан
}

\section{Түйін}

Бұл мақаланың мақсаты вакуумдық жабдық өндірісін инновациялық түрлендіру негізінде машина жасау кәсіпорындарында жаңа өнімдерді енгізу үрдісін зерттеу болып табылады. Қазақстандағы ірі кәсіпорындардың қызметі инновациялық белсенділіктің жеткіліксіз деңгейімен көрінуі, олардың жаһандық бәсекелестік жағдайында сипатталуымен айқындалады. Сондықтан инфрақұрылымды және өндірістік әлеуетті құру машина жасау кәсіпорындарының өндірістік қызметін тиімді басқарудың негізгі құрамдас бөлігі болып табылады. Бұл жағдай, ең алдымен, ірі кәсіпорындардың басшыларын алаңдатады, өйткені цифрлық технология жағдайында инновацияның дамуы отандық өнеркәсіптік кәсіпорындардың бәсекеге қабілеттілігіне, сонымен қатар экспорттық әлеуетіне үздіксіз әсер ету жағдаймен және ел экономикасының құрылымында теңгерімді қамтамасыз етеді. Өнеркәсіп өндірісінің барлық буындарының жұмысының тиімділігі мен сапасын арттыруға бағытталған ірі кәсіпкерлік субъъктілердің қызметіне экономикалық талдау жүргізу үлкен қызығушылыққа байланысты болады. Бұл бағыттағы тиісті жұмыс авторлардың көзқарасы бойынша, жасалып жатқан жұмыстар инновациялық экономика жағдайында өндірістік-шаруашылық қызметтің тиімділігін арттырудың жеке ғылыми-теориялық және тәжірибелік мәселелерін зерттеу ерекшеліктеріне байланысты шаралардың тұтас кешенін әзірлеуді талап етеді. Ғылыми мақалада авторлардың пікірінше, өндірістегі инвестициялық жоба машина жасау кәсіпорындарында инновацияны тиімді енгізуге негіз бола алады. Авторлар кәсіпорынның қаржы-шаруашылық қызметіне талдау жасаған және «Шығысмашзауыт» АҚ нақты зерттеу нысаны мысалында өнімді өндіру мен өткізуге кететін шығындарды азайтудың тәжірибелік шараларын әзірледі. Зерттеу нәтижелері - инновациялық жобада өндіріс шығындарын азайту және оларды тиімді басқару бойынша жобалардың тәжірибелік қолдану мүмкіндігі тұрғысынан машина жасау саласының көптеген шаруашылық жүргізуші субъектілерінің ерекше қызығушылығын тудырады.

Түйін сөздер: шығындарды басқару, инновациялар, вакуумдық жабдық, өнеркәсіптік кәсіпорындар, машина жасау, инвестициялық жоба

Дәйексөз алу үшін: Нұрмұхаметов Н.Н., Амерханова А.Б., Ауезова К.Т. (2021). Машина жасау кәсіпорындарындағы өндірістің вакуумдық жабдықтарының инновациялық трансформациясы. Экономика: стратегия және практика, 16(4), 18-33, https://doi.org/10.51176/1997-9967-2021-4 -18-33

* Хат-хабаршы авторы: Нұрмұхаметов Н.Н. - экономика ғылымдарының кандидаты, доцент «Л.Н. Гумилев атындағы Еуразия ұлттық университеті, Қ. Сәтбаев көш., 2, 010005, Нұр-Сұлтан, Қазақстан, 87056314503, e-mail: nyrbahit73@mail.ru

Мүдделер қақтығысы: авторлар мүдделер қақтығысының жоқтығын мәлімдейді.

Қаржыландыру: машина жасау кәсіпорындарында инвестициялық жобаны іске асыру шеңберінде жеке қаржыландыру.

Мақала редакцияға түсті: 01.12 .2021

Жариялау туралы шешім қабылданды: 24.12.2021

Жарияланды: 30.12.2021 


\title{
Инновационное преобразование производства вакуумного оборудования на предприятиях машиностроения
}

\author{
Нурмухаметов Н.Н. ${ }^{1 *}$, Амерханова А.Б. ${ }^{1}$, Ауезова К.Т. ${ }^{1}$ \\ ${ }^{1}$ НАО Евразийский национальный университет им. Л.Н. Гумилева, ул. К. Сатпаева, 2, 010005 , \\ Нур-Султан, Казахстан
}

\begin{abstract}
Аннотация
Целью написания статьи является исследование процесса внедрения новой продукции на предприятиях машиностроения на основе инновационного преобразования производства вакуумного оборудования. Деятельность крупных предприятий Казахстана характеризуется недостаточным уровнем инновационной активности, особенно в условиях глобальной конкуренции. Поэтому наращивание инфраструктуры и производственного потенциала является главным составляющим в эффективном управлении производственной деятельности предприятий машиностроения. Данная ситуация в первую очередь волнует руководителей крупных предприятий, поскольку развитие инновации в условиях цифровых технологий оказывает значимое влияние на конкурентоспособность, экспортный потенциал отечественных промышленных предприятий и может обеспечить сбалансированность структуры отраслей экономики страны. Все это обуславливает большой интерес у авторов в необходимости проведения экономического анализа деятельности субъектов крупного бизнеса, который будет направлен на повышение эффективности и качество работы всех звеньев промышленного производства. С точки зрения авторов практика требует разработки целого ряда комплексных мероприятий, связанных с особенностями изучения отдельных научно-теоретических и практических проблем повышения эффективности производственно-хозяйственной деятельности в условиях инновационной экономики. По мнению авторов данной статьи, инвестиционный проект может стать основой эффективного внедрения инновации на предприятиях машиностроения. Была проанализирована финансово-хозяйственная деятельность предприятия, разработаны практические меры по снижению затрат производства и реализации продукции на примере предприятия АО «Востокмашзавод», являющейся объектом данного исследования. Результатом исследования является - инвестиционный проект, который представляет особый интерес со стороны многих хозяйствующих субъектов машиностроительной отрасли и с точки зрения практической применимости проектов для снижения затрат на производство, и эффективностью управления ими.
\end{abstract}

Ключевые слова: управление затратами, инновации, вакуумное оборудование, промышленные предприятия, машиностроения, инвестиционный проект

Для цитирования: Нурмухаметов Н.Н., Амерханова А.Б., Ауезова К.Т. (2021). Инновационное преобразование производства вакуумного оборудования на предприятиях машиностроения. Экономика: стратегия и практика, 16(4), 18-33. https://doi.org/10.51176/1997-9967-2021-4-18-33

* Корреспондирующий автор: Нурмухаметов Н.Н. - кандидат экономических наук, ассоциированный профессор, НАО «Евразийский национальный университет им. Л.Н. Гумилева, ул. К. Сатпаева 2, 100005 , Нур-Султан, Казахстан, 87056314503, e-mail: nyrbahit73@mail.ru

Конфликт интересов: авторы заявляют об отсутствии конфликта интересов.

Финансирование: частное финансирование в рамках реализации инвестиционного проекта на предприятиях машиностроения.

Статья поступила в редакцию: 01.12 .2021

Принято решение о публикации: 24.12 .2021

Опубликовано: 30.12 .2021 


\section{Введение}

Глобальный кризис для отечественных предприятий машиностроения диктует новые условия для производства наукоемкой продукции. Создавшиеся трудности и условия, вызванные пандемией COVID-2019, однозначно повлияли на стратегию развития многих действующих компаний, путем внесения в содержание основных индикаторов производственной деятельности меры, связанные с вызовами цифровой экономики. Существуют самые разные технологии цифровизации в машиностроении [1]. В связи с этим в качестве позитивной тенденции следует выделить ряд мер, принимаемых по стимулированию в машиностроении более результативного инвестиционного климата [2].

Новые условия рынка оказали реальное влияние на уровень производства отечественной промышленной продукции, что обуславливает сокращение сбыта и снижение качественных характеристик конкурентных преимуществ машиностроительной продукции по сравнению с аналоговой продукцией конкурентов иностранных предприятий. Данная проблема отразилась в деятельности предприятий промышленности, которые были вынуждены сократить объемы производства. Однако стратегия развития предприятий машиностроения обеспечивала сохранение собственных производственных мощностей, цехов и структурных подразделений с целью обеспечения непрерывности производственного цикла. Несмотря на огромную производственную базу предприятий машиностроения, есть много нерешенных проблем, касающихся производственных мощностей предприятий машиностроительной отрасли. Как показывает практика, внедрение инновации на сумму менее $2 \%$ следует относить к усовершенствованию, а выше $10 \%$ - уже к креативному инновационному развитию [3].

Предприятие имеет производственный потенциал, производственные мощности и производственную базу, что позволяет ему обновлять основные фонды и увеличить выпуск продукции на основе реализации инвестиционного проекта - инновационного преобразования вакуумного производства продукции, направленной на снижение затрат производства и реализацию продукции.

\section{Литературный обзор}

Анализ научных работ, монографий и публикаций позволяет сделать вывод о том, что существует множество обоснованных научных принципов и методов, взглядов и рекомендаций ученых-экономистов, изучающих влияние инноваций и инвестиционных проектов на производственный процесс реального сектора экономики. Однако результаты многих работ по данной проблеме характеризуется выводами общего характера [4-6], мало работ, в которых рассматриваются реальные исследования по объектам производственной деятельности, что позволяют детально изучить современные подходы к управлению затратамипредприятия ивнедрениюновойпродукции на основе реализации инновационных проектов. Это причина обусловлена отсутствием доступности материалов со стороны предприятий для проведения анализа и разработки научно-обоснованных, и практикоориентированных стратегий управления современными промышленными компаниями.

Вопросы аналитического исследования деятельности предприятий в условиях кризиса и результативность внедрения инновации в реальный сектор экономики изучены многими авторами, к примеру, Борисов Б.Н. и Почукаева О.В. отмечают, что обновление производственно-технической базы реального сектора окажет существенное влияние на емкость внутреннего рынка инвестиционного оборудования. Увеличение внутреннего спроca будет обусловлено мультипликативными факторами, активизацию которых обеспечит высокий уровень межотраслевых связей отраслей машиностроения, выпускающих инвестиционное оборудование [7].

Кроме того, методы измерения влияния инвестиционного и инновационного факторов на функционирование отраслей, производств и предприятий позволит получить количественные оценки воздействия этих факторов на динамику выпуска продукции, конкурентоспособность, эффективность производственной деятельности и формирование инвестиционных ресурсов для активизации инновационной деятельности [8].

В зарубежной практике применяются следующие показатели оценки эффективности инновационной деятельности в соответствии с рекомендациями ЮНИДО (Организации Объединенных Наций по промышленному развитию) [9]:

- чистый дисконтированный доход;

- внутренняя норма прибыли, или коэффициент дисконтирования;

- норма прибыли.

Инновации - один из главных факторов, который повышает эффективность деятельности компании. Введение любой инновации составляет определенную степень риска. В связи с этим инвестиционный проект может быть нереализованным, а 
также неэффективным. Машиностроительная отрасль имеет свою специфику. Для этой отрасли нужно постоянно заниматься процессом повышения качества продукции. Владельцы и менеджеры компаний часто осуществляют это с помощью внедрения передовых научно-технических разработок. Они внедряются вместе с обновлением значительной части оборудования, которое используется сотрудниками компании во время рабочего процесса [10].

Целью оценки инновационного потенциала промышленного предприятия является определение направлений инновационного развития, обеспечивающих возможности перехода предприятия на выпуск конкурентоспособной продукции при существенном повышении своей устойчивости и гибкости по отношению к переменам во внешней среде [11].

В целом, обзор литературы позволяет сделать вывод об обеспечении эффективности реализации инвестиционно-инновационных проектов, направленных на повышение роли реального сектора экономики в условиях глобальных изменений и для достижения главных целей стратегического развития Казахстана.

\section{Методология}

В процессе проведения научного исследования применена методология классической науки. В качестве основных методов исследования были использованы аналитические, математические, синтетические методы исследования и метод гипотез. Также был использован метод проектирования инвестиционных проектов, в рамках которого были проанализированы производственно-финансовая деятельность исследуемого объекта, а также использованы такие методы, как анализ чувствительности и метод сценариев, для выявления возможных рисков инновационного проекта.

Для проведения исследования процесса управления затратами предприятия в условиях экономического спада был проведен анализ информационной составляющей проекта и его влияния на производственно-хозяйственную деятельность субъектов крупного бизнеса машиностроительной отрасли. Результаты исследования были использованы для реализации региональной промышленной политики развития Восточно-Казахстанской области. Алгоритм исследования основывался на поэтапном проведении расчета экономической эффективности инновационноинвестиционного проекта путем внедре- ния новой продукции на основе вакуумного преобразования производства машиностроительной отрасли, в рамках которой были проанализированы в отдельности все составные элементы производственно-хозяйственной деятельности предприятия. Математический метод позволил выявить пробелы в производственном процессе, связанные с неэффективностью управления затратами при реализации проекта. Следующий этап алгоритма исследования заключался в оценке эффективности инновационноинвестиционного проекта, определении его потенциальной привлекательности для предприятия и поиске новых источников финансирования. На заключительном этапе исследования был применен синтетический метод и метод гипотез. В рамках основной гипотезы было определено, что для обеспечения рациональности управления затратами в условиях ускорения развития цифровой экономики имеет место необходимость реализации инновационно-инвестиционных проектов, ориентированных на реализацию конкурентоспособной машиностроительной продукции. Информационной базой исследования послужили официальная статистическая информация в области развития машиностроительной отрасли, научнопериодические журналы, в том числе ближнего и дальнего зарубежья.

\section{Результаты}

Объектом исследования является $\mathrm{AO}$ «Востокмашзавод» как субъект машиностроительной отрасли Казахстана, производящий высокотехнологичную продукцию изделия ковши.

По номенклатуре выпускаемых изделий ковши относятся к разовой продукции и предназначены для выплавки ферросплавов. В настоящее время предприятие осуществляет производство нескольких разновидностей ковшей, разных объёмов: ковш сварной для выплавки ферросплавов (V-4.0 м $\left.{ }^{3}\right)$; ковш для углеродистого феррохрома (V-1,7 м $\left.; 2.3 \mathrm{~m}^{3}\right)-$ феррохром высоколегированный металл; ковш для ферросиликохрома $\left(\mathrm{V}-2.3 \mathrm{M}^{3}\right)$ и ковши разливочные для хранения, транспортировки ферросплавов. Вес указанных ковшей колеблется в пределах от 3300-7300 кг.

В качестве объекта инновационного внедрения в производство является ковш сварной - М720-484, предназначенный для ферросплавов (выплавка, хранение, транспортировка) - объем 8 м $^{3}$. Естественно, данный ковш весит значительно больше вышеперечисленных, оставляет - 12840 кг. 
Инновационность данной продукции определено применением прогрессивной технологии и высокопрочных характеристик сварных швов ковшей, что обуславливается прохождением ультразвукового контроля качества. Все элементы металлоконструкции выполняются из низколегированной стали, что обеспечивает ее повышенную прочность и долговечность. Быстроизнашивающиеся части и режущая часть ковшей изготавливаются из высокопрочной и износоустойчивой стали импортного производства.

Внедрение инновационного оборудования способствует тому, что на стадии проектирования нового изделия активно используются VR- и AR-технологии. Создание эскизов в виртуальном пространстве (VR) позволяет оперативно изменять характеристики и внешний вид будущего изделия. Применение данных технологий снижает себестоимость и риски при производстве новых изделий. Дополненная реальность (AR) используется при планировании и организации производственных линий, внедрении и расстановке новой технологии и оборудования. Применение прогрессивных виртуальных технологий способствует снижению трудоемкости, повышению производительности труда, увеличению гибкости оборудования и скорости обработки деталей, что особенно важно в условиях современной организации производственного процесса, ориентированного на массово-поточное производство при широкой номенклатуре и малых объемах выпуска изделий [12].

Приобретение оборудования осуществлялось лизингом, был оформлен договор финансового лизинга. Участники лизинговой операции в полной мере определили выгоду от реализации инновационного проекта. Заключение договора лизинга обусловлено внесением авансового платежа в размере $15 \%$ от стоимости оборудования, оставшаяся часть включается в лизинговый платеж, оплата которого осуществляется ежемесячно в течение 5 лет. Для оплаты $15 \%$ авансового платежа руководство предприятия получил кредит на 2,5 года с процентной ставкой $17 \%$ годовых. Погашение кредита осуществляется по методу уменьшения остатка.

План инновационного преобразования вакуумного производство - инвестиционного проекта включает три этапа реализации:

I этап - Строительно-монтажные и пусконаладочные работы (срок реализации 2 месяца);

II этап - Освоение производства (срок реализации -2 месяца); -5 лет)

III этап - Производство (срок реализации

Оценка эффективности инвестиционного проекта определяется его потенциальной привлекательностью для предприятия и поиском новых источников финансирования.

Экономическая оценка эффективности инвестиционного проекта: за весь срок действия договора лизинга, затраты предприятия составят в сумме 6515,81 млн. тенге, из них амортизационные отчисления на производственное оборудование составляет 40375,0 млн. тенге и 24 731, 0 млн. тенге лизинговые платежи.

Для определения эффективности реализации проекта были рассчитаны накладные расходы по инновационному проекту на основании проектной документации и полученные данные приведены в таблице 1.

Таблица 1 - Накладные расходы инвестиционного проекта

Table 1 - Overhead costs of an investment project

\begin{tabular}{|c|c|}
\hline Статья затрат & $\begin{array}{r}\text { Сумма в год } \\
\text { (тыс. тенге) }\end{array}$ \\
\hline $\begin{array}{l}\text { Расходы на содержание } \\
\text { эксплуатацию оборудования }\end{array}$ & 2492,71 \\
\hline Цеховые расходы на управление & 1117,41 \\
\hline $\begin{array}{l}\text { Административно-управленческие } \\
\text { расходы }\end{array}$ & 357,96 \\
\hline $\begin{array}{l}\text { Зарплата административно- } \\
\text { управленческого и } \\
\text { производственного персонала, в том } \\
\text { числе отчисления на заработную } \\
\text { плату }\end{array}$ & 1356,57 \\
\hline Итого & 5324,65 \\
\hline
\end{tabular}

Проведенный анализ производственнохозяйственной деятельности предприятия за 2016-2020 гг. позволил получить обобщенные аналитические расчеты о расходах по обслуживанию основного производства, полной и производственной себестоимости продукции на основе анализа расходов на содержание и эксплуатацию оборудования, цеховых расходов на управления и административно-управленческие расходы, результаты сведены в таблицу 2.

В целом данные таблицы 2 свидетельствует, что предприятие на исследуемый период имеет положительную динамику развития, но при этом издержки производства в рассматриваемый период величина постоянная.

По расчетным данным таблицы 3 денежных потоков, рассчитаны показатели экономической эффективности проекта, результаты которого приведены в таблице 4. 
Таблица 2 - Издержки производства и реализации продукции

Table 2 - Costs of production and sales of products

\begin{tabular}{|l|c|c|c|c|c|c|}
\hline \multirow{2}{*}{\multicolumn{1}{|c|}{ Показатель }} & \multicolumn{5}{|c|}{ Расчетный период тыс. тенге } \\
\cline { 2 - 7 } & 2015 г. & 2016 г. & 2017 г. & 2018 г. & 2019 г. & 2020 г. \\
\hline Объем производства & 2036,4 & 7315,3 & 7315,3 & 7315,3 & 7315,3 & 7315,3 \\
\hline Прямые материальные затраты & 445,37 & 1599,9 & 1599,9 & 1599,9 & 1599,9 & 1599,9 \\
\hline Расходы на оплату труда & 89,72 & 1076,7 & 1076,7 & 1076,7 & 1076,7 & 1076,7 \\
\hline Амортизационные отчисления & 0,00 & 2563,6 & 2563,6 & 1388,6 & 0,00 & 0,00 \\
\hline $\begin{array}{l}\text { Налоги, относимые на } \\
\text { себестоимость }\end{array}$ & 23,33 & 279,93 & 279,93 & 279,93 & 279,93 & 279,93 \\
\hline Издержки производства & 638,96 & 7090,2 & 6857,7 & 5472,6 & 4023,7 & 4023,7 \\
\hline $\begin{array}{l}\text { Издержки производства без } \\
\text { амортизации }\end{array}$ & 638,96 & 4526,6 & 4294,2 & 4083,9 & 4023,6 & 4023,6 \\
\hline $\begin{array}{l}\text { Общепроизводственные и } \\
\text { общехозяйственные расходы без } \\
\text { амортизационных отчислений } \\
\text { и налогов, относимых на } \\
\text { себестоимость }\end{array}$ & 80,53 & 1570,1 & 1337,7 & 1127,5 & 1067,2 & 1067,2 \\
\hline Издержки по сбыту продукции & 638,96 & 7090,3 & 6857,3 & 5472,6 & 4023,7 & 4023,7 \\
\hline $\begin{array}{l}\text { Постоянные издержки без } \\
\text { амортизации }\end{array}$ & 163,00 & 2500,9 & 2268,5 & 2058,3 & 1997,9 & 1997,9 \\
\hline Переменные издержки & 475,96 & 2025,7 & 2025,7 & 2025,7 & 2025,7 & 2025,7 \\
\hline $\begin{array}{l}\text { Производственная себестоимость } \\
\text { единицы продукции }\end{array}$ & 0,31 & 0,97 & 0,94 & 0,75 & 0,55 & 0,55 \\
\hline
\end{tabular}

Примечание - Источник [13]

Таблица 3 - Денежные потоки для оценки экономической эффективности инвестиционного проекта Table 3 - Cash flows for assessing the economic efficiency of an investment project

\begin{tabular}{|c|c|c|c|c|c|c|}
\hline \multirow{2}{*}{ Показатель } & \multicolumn{6}{|c|}{ Расчетный период (тыс. тенге) } \\
\hline & 2015 г. & 2016 г. & 2017 г. & 2018 г. & 2019 г. & 2020 г. \\
\hline \multicolumn{7}{|c|}{ Операционная деятельность } \\
\hline Денежные притоки & 3414,99 & 12267,59 & 12267,59 & 12267,59 & 12267,59 & 12267,59 \\
\hline Выручка от реализации продукции & 3414,99 & 12267,59 & 12267,59 & 12267,59 & 12267,59 & 12267,59 \\
\hline Денежные оттоки & 1378,71 & 9477,06 & 9300,43 & 8255,88 & 6884,29 & 6810,78 \\
\hline Налоги и сборы & 643,04 & 1226,27 & 1282,05 & 1622,64 & 1699,99 & 1723,20 \\
\hline Внереализационные расходы & 96,72 & 3724,26 & 3724,26 & 2549,28 & 1160,66 & 1063,94 \\
\hline \multicolumn{7}{|c|}{ Инвестиционная деятельность } \\
\hline $\begin{array}{l}\text { Денежные притоки (ликвидационная } \\
\text { стоимость) }\end{array}$ & 0,00 & 0,00 & 0,00 & 0,00 & 0,00 & 0,00 \\
\hline $\begin{array}{l}\text { Издержки производства и сбыта продук- } \\
\text { ции без амортизационных отчислений }\end{array}$ & 638,96 & 4526,53 & 4294,11 & 4083,96 & 4023,63 & 4023,63 \\
\hline $\begin{array}{l}\text { Расходы на содержание переданного по } \\
\text { договору лизинга имущеста (включая } \\
\text { амортизацию) }\end{array}$ & 96,72 & 3724,26 & 3724,26 & 2549,28 & 1160,66 & 1063,94 \\
\hline $\begin{array}{l}\text { Сальдо денежного потока от операцион- } \\
\text { ной деятельности }\end{array}$ & 2036,28 & 2790,53 & 2967,16 & 4011,71 & 5383,30 & 5456,81 \\
\hline Денежные оттоки & $-712,50$ & 0,00 & 0,00 & 0,00 & 0,00 & 0,00 \\
\hline Общие капиталовложения & $-712,50$ & 0,00 & 0,00 & 0,00 & 0,00 & 0,00 \\
\hline $\begin{array}{l}\text { Вложения средств в дополнительные } \\
\text { фонды }\end{array}$ & 0,00 & 0,00 & 0,00 & 0,00 & 0,00 & 0,00 \\
\hline $\begin{array}{l}\text { Сальдо денежного потока от инвести- } \\
\text { ционной деятельности }\end{array}$ & $-712,50$ & 0,00 & 0,00 & 0,00 & 0,00 & 0,00 \\
\hline Сальдо суммарного потока & 1323,78 & 2790,53 & 2967,16 & 4011,71 & 5383,30 & 5456,81 \\
\hline Накопленное сальдо суммарного потока & 1323,78 & 4114,31 & 7081,48 & 11093,19 & 16476,4 & 21933,30 \\
\hline
\end{tabular}

Примечание - Источник [13] 
Таблица 4 - Показатели экономической эффективности инвестиционного проекта

Table 4 - Indicators of economic efficiency of an investment project

\begin{tabular}{|c|c|}
\hline Показатель & Методика расчета \\
\hline $\begin{array}{l}\text { Чистая приведенная } \\
\text { стоимость (NPV) }\end{array}$ & $\begin{array}{l}\mathrm{NPV}=\left[2146,10:(1+0,17)^{1}+1395,82:\right. \\
\left.(1+0,17)^{2}+\ldots+4559,03:(1+0,17)^{6}\right]-6515,81=5839,24\end{array}$ \\
\hline Индекс прибыльности (PI) & $\mathrm{PI}=\left[2 \quad 146,10:(1+0,17)^{1}+\ldots+4\right.$ 559,03:(1+0,17) $\left.{ }^{6}\right]: 6515,81=1,90$ \\
\hline Норма окупаемости (IRR) & $\begin{array}{l}\text { IRR: } 6515,81=2146,10:(1+\text { IRR })^{1}+1395,82:(1+\text { IRR })^{2}+\ldots+4559,03: \\
:(1+\text { IRR })^{6}=41,5 \%\end{array}$ \\
\hline $\begin{array}{l}\text { Модифицированная внутрен- } \\
\text { няя норму доходности } \\
\text { (MIRR) }\end{array}$ & $\begin{array}{l}\text { MIRR - [2 146,10*(1+0,17)5+1 395,82*(1+0,17)4+ ..+4 559,03*(1+0,18)0 ]: } \\
:(1+\text { MIRR } 6=30,17 \%\end{array}$ \\
\hline Срок окупаемости (РP) & $P P=2+\frac{(6515,81-4826,81)}{2967,16}=2,57$ \\
\hline
\end{tabular}

Примечание - Источники [12, 13]

По данным таблицы 4 можно сделать следующие выводы:

1. Положительная величина $\mathrm{NPV}=5$ 839,24 , говорит о том, что денежные потоки по проекту покрывают инвестиционные затраты, a значит проект прибыльный и может быть принят для его реализации.

2. Индекс прибыльности, показывает относительную прибыльность проекта, или дисконтированную стоимость денежных поступлений от проекта в расчете на единицу вложений, при этом показатель PI $>1$, то современная стоимость денежного потока проекта превышает первоначальные инвестиции, обеспечивая тем самым наличие положительной величины NPV, при этом норма рентабельности превышает заданную, т.е. проект следует принятью.
3. Норма окупаемости (IRR) проекта равна $41,5 \%$ и показывает, сколько в среднем за весь период инвестирования предприятие зарабатывает на данные вложения.

4. Модифицированная внутренняя норма доходности используется при неординарных денежных потоках проекта и для правильной оценки ставки реинвестирования, и показатель $30,17 \%$ снимает проблему множественности ставки рентабельности.

5. Показатель срока окупаемости проекта составляет 2,7 года, что подтверждает ликвидность проекта, но и его рискованность. Очень важно произвести расчет дисконтированного срока окупаемости, для этого необходимо привести денежные потоки к сопоставимому виду, то есть продисконтировать по ставке $17 \%$ (таблица 5).

Таблица 5 - Дисконтированные денежные потоки инвестиционного проекта

Table 5 - Discounted cash flows of the investment project

\begin{tabular}{|c|c|c|c|}
\hline $\begin{array}{c}\text { Расчетный } \\
\text { период }\end{array}$ & Абсолютное значение & $\begin{array}{c}\text { Коэффициент дисконтирова- } \\
\text { ния }\end{array}$ & Дисконтированное значение \\
\hline 0 & $-6515,81$ & & 1740,41 \\
\hline 1 & 2036,28 & $(1+0,17)^{1}=1,17$ & 2038,52 \\
\hline 2 & 2790,53 & $(1+0,17)^{2}=1,37$ & 1852,61 \\
\hline 3 & 2967,16 & $(1+0,17)^{3}=1,60$ & 2140,85 \\
\hline 4 & 4011,71 & $(1+0,17)^{4}=1,87$ & 2455,38 \\
\hline 5 & 5383,30 & $(1+0,17)^{5}=2,19$ & 2127,28 \\
\hline 6 & 5456,81 & $(1+0,17)^{6}=2,57$ & \\
\hline
\end{tabular}

Примечание - Источники [12, 13] 
На основе данных таблицы 3 рассчитаны показатели оценки экономической эффективности реализации инвестиционного проекта. Итоги сведены в таблицу 6, коэффициент DPP равен 3,41 .
Таким образом, с точки зрения экономической оценки эффективности проект является прибыльным, покрывает все инвестиционные затраты, связанные с его реализацией, и окупается в течение 3,5 лет.

Таблица 6 - Показатели оценки экономической эффективности реализации инвестиционного проекта

Table 6 - Indicators for assessing the economic efficiency of the implementation of an investment project

\begin{tabular}{|l|c|}
\multicolumn{1}{|c|}{ Критерий } & Значение \\
\hline Чистая приведенная стоимость (NPV) & 5839,24 тыс. тенге \\
\hline Индекс прибыльности (PI) & 1,9 \\
\hline Внутренняя норма доходности (IRR) & $41,5 \%$ \\
\hline Модифицированная внутренняя норма доходности (MIRR) & $30,2 \%$ \\
\hline Срок окупаемости (PP) & 2 года 7 мес. \\
\hline Срок окупаемости (DPP) & 3 года 5 мес. \\
\hline
\end{tabular}

Примечание - Источники $[11,13]$

Для расчета финансовой устойчивости проекта проанализировали агрегированный баланс, отчет

о прибылях и убытках таблица и финансовоинвестиционный бюджет инвестиционного проекта вакуумного производство.

Проанализировав агрегированный баланс проекта, можно сделать следующие выводы:

- удельный вес оборотных активов в структуре баланса свидетельствует о формировании достаточно мобильной структуры активов, способствующей ускорению оборачиваемости средств проекта;

- основной вклад в формирование оборотных активов составили денежные средства: данная структура с низкой долей задолженности и высоким уровнем денежных средств может свидетельствовать о благополучном состоянии расчетов предприятия с потребителями и о выборе подходящей политики продаж;

- преобладание кредиторской задолженности над дебиторской свидетельствует о том, что проект, реализованный на предприятии, финансировал свои запасы и отсрочки платежей своих должников за счет неплатежей коммерческим кредиторам (то есть бюджету, внебюджетным фондам и др.);

- удельный вес в структуре пассивов приходится на собственные средства, а именно на нераспределенную прибыль;

- увеличение собственного капитала свидетельствует об увеличении финансовой устойчивости проекта;

- основными источниками формирования совокупных активов является собственный капитал;

- преобладание краткосрочных источников в структуре заемных средств является негативным фактом, который характеризует ухудшение структуры баланса и повышение риска утраты финансовой устойчивости.

Для определения экономической эффективности проекта рассчитан прогнозный отчет о прибылях и убытках с целью расчета рентабельности проекта и финансовоинвестиционный бюджет для анализа финансовой реализуемости проекта.

Результаты анализа свидетельствует, что на протяжении всего срока реализации проекта присутствует положительное сальдо.

С целью оценки финансовой привлекательности инвестиционного проекта проведен анализ на финансовую состоятельность предприятия на основе коэффициентов финансовой устойчивости, ликвидности, деловой активности и рентабельности. Расчетные данные сведены в таблицу 7.

В связи с тем, что инвестиционный проект финансируется за счет лизинга доля заемного капитала не так велика и у предприятия остается достаточно средств для погашения своих обязательств. Снижение коэффициента долгосрочного привлечения заемных средств свидетельствует о том, что предприятия в меньшей степени зависит от внешнего финансирования.

Различные показатели ликвидности не только дают разностороннюю характеристику устойчивости финансового состояния предприятия при разной степени учета ликвидных средств, но и отвечают интересам различных внешних показателей аналитической информации. 
Таблица 7 - Оценка финансовой эффективности инвестиционного проекта Table 7 - Assessment of the financial efficiency of an investment project

\begin{tabular}{|c|c|c|c|c|c|c|}
\hline \multirow{2}{*}{ Наименование } & \multicolumn{6}{|c|}{ Год/Значение показателей } \\
\hline & 2015 г. & $2016 \Gamma$ & $2017 \Gamma$ & $2018 \Gamma$ & $2019 \Gamma$ & 2020 г. \\
\hline \multicolumn{7}{|c|}{ Коэффициенты финансовой устойчивости } \\
\hline Коэффициент финансовой устойчивости & 0,17 & 0,39 & 0,57 & 0,73 & \multirow{2}{*}{$\begin{array}{l}0,82 \\
0,00\end{array}$} & 0,88 \\
\hline Коэффициент платежеспособности & 0,12 & 0,09 & 0,03 & 0,00 & & 0,00 \\
\hline $\begin{array}{l}\text { Коэффициент долгосрочного привлече- } \\
\text { ния заемных средств }\end{array}$ & 0,58 & 0,14 & 0,03 & 0,00 & 0,00 & 0,00 \\
\hline $\begin{array}{l}\text { Коэффициент покрытия долгосрочных } \\
\text { вложений }\end{array}$ & 0,15 & 0,15 & 0,14 & 0,00 & 0,00 & 0,00 \\
\hline \multicolumn{7}{|c|}{ Коэффициенты ликвидности } \\
\hline Коэффициент текущей ликвидности & 0,44 & 1,04 & 2,09 & 3,72 & 5,51 & 8,39 \\
\hline Коэффициент быстрой ликвидности & 0,44 & 1,04 & 2,08 & 3,71 & 5,50 & 8,37 \\
\hline Коэффициент абсолютной ликвидности & 0,03 & 0,50 & 1,36 & 3,32 & 5,38 & 7,99 \\
\hline \multicolumn{7}{|c|}{ Коэффициенты деловой активности } \\
\hline Коэффициент оборачиваемости активов & 0,33 & 1,15 & 0,92 & 0,79 & 0,65 & 0,55 \\
\hline $\begin{array}{l}\text { Коэффициент оборачиваемости собствен- } \\
\text { ного капитала }\end{array}$ & 4,71 & 3,39 & 1,65 & 1,07 & 0,80 & 0,62 \\
\hline $\begin{array}{l}\text { Коэффициент оборачиваемости дебитор- } \\
\text { ской задолженности }\end{array}$ & 360,00 & 102,06 & 120,06 & 48,06 & 12,06 & 30,06 \\
\hline \multicolumn{7}{|c|}{ Коэффициенты рентабельности } \\
\hline Чистая рентабельность продаж & 0,60 & 0,32 & 0,33 & 0,42 & 0,44 & 0,44 \\
\hline Чистая рентабельность активов & 0,20 & 0,36 & 0,30 & 0,33 & 0,29 & 0,24 \\
\hline $\begin{array}{l}\text { Чистая рентабельность собственного } \\
\text { капитала }\end{array}$ & 2,81 & 1,07 & 0,55 & 0,45 & 0,35 & 0,28 \\
\hline
\end{tabular}

Примечание - Источники [13, 14]

Коэффициенты ликвидности позволяют определить способность предприятия оплатить свои краткосрочные обязательства в течение отчетного периода, в нашем примере, обеспечивает резервный запас для компенсации убытков, которые может понести предприятие при размещении и ликвидации всех оборотных активов, кроме наличности.

Деловая активность в финансовом аспекте проявляется, прежде всего, в скорости оборота средств, и как комплексный показатель организационно-технического уровня предприятия. Коэффициенты оборачиваемости имеют тенденцию к снижению, что говорит об ускорении оборачиваемости.

Расчет коэффициентов рентабельности, исходя из приведенного выше деления, позволяет достаточно полно оценить эффективность деятельности предприятия. Так, рентабельность реализованной продукции показывает, что в среднем предприятие получает 23 тиын чистой прибыли с 1 тенге выручки. Но этот коэффициент не позволяет оценить эффективность использования предприятием его активов: основных и оборотных средств и его пассивов: собственных и заемных средств.
Оценить эффективность использования основных и оборотных средств позволяет сделать вывод о том, что 1 тенге всех вложенных в предприятие средств, в среднем за весь жизненный срок проекта приносит 21 тенге.

Коэффициент рентабельности собственного капитала свидетельствует, что при реализации проекта один тенге инвестирования принесет предприятию 35 тенге чистой прибыли.

Таким образом, расчет и сопоставление между собой коэффициентов этих четырех групп позволяет нам сделать вывод, что принятие столь рентабельного проекта может, повысить рентабельность самого предприятия, на котором данный проект будет реализован, следовательно с точки зрения финансовой эффективности рассматриваемый проект финансово устойчив.

Проведена оценка возможных рисков в процессе планирования проекта, которые определены с помощью методов анализ чувствительности и метода сценариев.

В качестве критерия для анализа рисков инвестиционного проекта определены чистая текущая стоимость проекта (NPV), (таблица 
8), и внутренняя норма доходности (IRR), (таблица 9), с учетом различных базовых отклонений выбранных факторов риска объема реализации, цены на сырье и условия финансирования.

По данным таблицы 8 можно сделать вывод о наиболее критических факторах инвестиционного проекта, в нашем случае критическим фактором оказался физический объем вырабатываемой электроэнергии. В дальнейшем при принятии проекта необходимо провести детальный анализ чувствительности по факторам, влияющим на изменения объема реализации. Результаты проведенного анализа чувствительности показателя IRR приведены в таблице 9.

Таблица 8 - Анализ чувствительности инвестиционного проекта по NPV

Table 8 - Analysis of the sensitivity of an investment project by NPV

\begin{tabular}{|c|c|c|c|}
\hline \multirow{2}{*}{$\begin{array}{c}\text { Отклонение от базового } \\
\text { значения, \% }\end{array}$} & \multicolumn{3}{|c|}{$\begin{array}{c}\text { NPV при различных отклонениях } \\
\text { от базового значения }\end{array}$} \\
\cline { 2 - 4 } & $\begin{array}{c}\text { Объем выработки } \\
\text { прддукции, тыс. тенге }\end{array}$ & $\begin{array}{c}\text { Цена на сырье, } \\
\text { тыс. тенге }\end{array}$ & $\begin{array}{c}\text { Лизинговый платеж, } \\
\text { тыс. тенге }\end{array}$ \\
\hline$-30 \%$ & $-3083,60$ & 6914,54 & 6121,97 \\
\hline$-15 \%$ & 1073,34 & 6372,41 & 5676,12 \\
\hline $0 \%$ & 5839,24 & 5839,24 & 5839,24 \\
\hline $15 \%$ & 9387,20 & 4088,13 & 4784,42 \\
\hline $30 \%$ & 13544,14 & 3254,99 & 4338,57 \\
\hline
\end{tabular}

Примечание - Источник [14]

Таблица 9 - Анализ чувствительности инвестиционного проекта по IRR Table 9 - Analysis of the sensitivity of the investment project by IRR

\begin{tabular}{|c|c|c|c|}
\hline \multirow{2}{*}{$\begin{array}{c}\text { Отклонение от базового } \\
\text { значения, } \%\end{array}$} & \multicolumn{2}{|c|}{ IRR при различных отклонениях от базового значения } \\
\cline { 2 - 4 } & $\begin{array}{c}\text { Объем выработки } \\
\text { продукции }\end{array}$ & Цены на сырье & Лизинговый платеж \\
\hline$-30 \%$ & $2,00 \%$ & $41,99 \%$ & $41,28 \%$ \\
\hline$-15 \%$ & $21,68 \%$ & $40,04 \%$ & $39,68 \%$ \\
\hline $0 \%$ & $41,46 \%$ & $41,46 \%$ & $41,46 \%$ \\
\hline $15 \%$ & $52,56 \%$ & $36,05 \%$ & $36,42 \%$ \\
\hline $30 \%$ & $65,81 \%$ & $34,01 \%$ & $34,75 \%$ \\
\hline
\end{tabular}

По данным таблицы 9 показана зависимость от физического объема выработки электроэнергии. Вследствие чего в ходе реализации проекта следует уделить больше внимания совершенствованию внутреннего менеджмента предприятия и ввести специальные меры по повышению производительности. Так же можно выделить незначительную зависимость показателей IRR и NPV от фактоpa материальных издержек, устранение которого целесообразно путем улучшения отношения с поставщиками, заключив долгосрочные контракты, позволяющие, возможно, снизить закупочную цену сырья.
Анализ чувствительности очень нагляден, однако главным его недостатком является то, что анализируется влияние только одного из факторов, а остальные считаются неизменными. На практике же обычно изменяются сразу несколько показателей. Оценить подобную ситуацию и скорректировать NPV и IRR проекта на величину риска помогает сценарный анализ. Рассмотрим три возможных сценария (таблица 10): пессимистический - 25\%; наиболее вероятностный $-50 \%$ и оптимистический $-25 \%$. Для каждого из сценария рассчитаем NPV и IRR [13]. 
Таблица 10 - Анализ сценариев (тыс. тенге)

Table 10 - Scenario analysis (thousand tenge)

\begin{tabular}{|c|c|c|c|c|c|c|}
\hline \multirow[b]{2}{*}{ Сценарий } & \multirow[b]{2}{*}{$\begin{array}{l}\text { Вероят- } \\
\text { ность, \% }\end{array}$} & \multicolumn{3}{|c|}{ Факторы риска } & \multirow[b]{2}{*}{$\begin{array}{l}\text { NPV про- } \\
\text { екта }\end{array}$} & \multirow[b]{2}{*}{ IRR проект, } \\
\hline & & $\begin{array}{l}\text { Объем вы- } \\
\text { работки }\end{array}$ & $\begin{array}{c}\text { Цены } \\
\text { на } \\
\text { сырье }\end{array}$ & $\begin{array}{c}\text { Лизинговый } \\
\text { платеж }\end{array}$ & & \\
\hline Пессимистический & $-25 \%$ & 5486,40 & 0,16 & 870,50 & $-51,31$ & 16,77 \\
\hline $\begin{array}{l}\text { Наиболее вероятност- } \\
\text { ный }\end{array}$ & $50 \%$ & 7315,20 & 0,22 & 1160,66 & 5839,24 & 41,50 \\
\hline Оптимистический & $25 \%$ & 9144,00 & 0,27 & 1450,83 & 10511,85 & 56,30 \\
\hline
\end{tabular}

Проект считается устойчивым, если при всех сценариях он оказывается эффективным и финансово реализуемым, в нашем случае при реализации пессимистического сценария возможны неблагоприятные последствия, которые можно устранить мерами, предусмотренными организационноэкономическим механизмом проекта.

Согласно проведенному расчету, связанному с критерием NPV - 67,4\%, риск приходится на единицу дохода. При расчете коэффициента вариации внутренней доходн- ости проекта его значение свидетельствует о том, что на $1 \%$ ожидаемой доходности приходится 0,54 единиц риска. Столь высокий риск компенсируется высокой доходностью проекта.

В таблице 11 показана зависимость от физического объема выработки электроэнергии. Вследствие чего в ходе реализации проекта следует уделить больше внимания совершенствованию внутреннего менеджмента предприятия и ввести специальные меры по повышению производительности.

Таблица 11 - Анализ чувствительности инвестиционного проекта по IRR (\%)

Table 11 - Analysis of the sensitivity of the investment project by IRR (\%)

\begin{tabular}{|c|c|c|c|}
\hline \multirow{2}{*}{$\begin{array}{c}\text { Отклонение от базового } \\
\text { значения, \% }\end{array}$} & \multicolumn{2}{|c|}{ IRR при различных отклонениях от базового значения } \\
\cline { 2 - 4 } & Объем выработки продукции & Цены на сырье & Лизинговый платеж \\
\hline$-30 \%$ & $2,00 \%$ & $41,99 \%$ & $41,28 \%$ \\
\hline$-15 \%$ & $21,68 \%$ & $40,04 \%$ & $39,68 \%$ \\
\hline $0 \%$ & $41,46 \%$ & $41,46 \%$ & $41,46 \%$ \\
\hline $15 \%$ & $52,56 \%$ & $36,05 \%$ & $36,42 \%$ \\
\hline $30 \%$ & $65,81 \%$ & $34,01 \%$ & $34,75 \%$ \\
\hline
\end{tabular}

Можно выделить незначительную зависимость показателей IRR и NPV от фактора материальных издержек, устранение которого целесообразно путем улучшения отношения с поставщиками, заключив долгосрочные контракты, которые возможно позволят снизить закупочную цену сырья. Анализ чувствительности очень нагляден, однако главным его недостатком является то, что анализируется влияние только одного из факторов, а остальные считаются неизменными. На практике же обычно изменяются сразу несколько показателей. Оценить подобную ситуацию и скорректировать NPV и IRR проекта на величину риска помогает сценарный анализ.

\section{Обсуждение}

Приоритетом развития по результатам внедрения инновационного проекта для предприятия является долгосрочное развитие прямых экономических связей с потенциальными потребителями данного вида продукции, потому что установление надежных и постоянных связей позволяет создавать условия для стабильного наращивания объемов производства по оговоренной номенклатуре металлургического оборудования.

Освоив производство ковша большой емкости V-8 м³, предприятие откроет новые перспективы. При выпуске уникальных ковшей внимание заказчиков можно привлечь тем, что производительность ковша объемом $8 \mathrm{~m}^{3}$ 
возрастает, так как рабочая емкость сварного ковша увеличивается до 12500 кг, или на 44\%. Это позволит предприятиям-заказчикам увеличить выплавку ферросплавов в единицу времени, т.е. повысить производительность металлургического оборудования, задействованного в производстве. Выпуск данной продукции является прибыльным и рентабельным, поэтому в условиях предприятия данный факт является резервом увеличения доходов от производства сварных ковшей.

При этом, необходимо отметить следующие направления повышения эффективности деятельности предприятия: повышение в общем объеме товарной продукции удельного веса рентабельных видов продукции; увеличение объемов производства за счет освоения нового вида продукции, расширение возможностей для сбыта новой продукции, за счет повышения технических характеристик ковшей. Для осуществления проекта потребуется произвести ремонт цеха и закупить оборудование.

Для снижения уровня влияния рисков, необходимо применение взаимодополняющих путей: меры, обеспечивающие выполнение контрактных обязательств на стадии заключения контрактов, и контроль управленческих решений в процессе реализации проекта. Первый путь в мировой практике осуществляется выбором следующих вариантов действий:
- страхование;

- обеспечение (в случае кредитного договора) в форме залога, гарантий, поручительств, неустойки или удержания имущества должника;

- постадийное разделение процесса удержания ассигнований проекта;

- д диверсификация инвестиций.

Варианты управленческих решений в целях снижения риска могут осуществляться следующими приемами:

- резервирование средств на покрытие непредвиденных расходов;

- реструктурирование кредитов.

В связи с тем, что рынок страхования проектных рисков еще плохо развит в Казахстане, снижение риска на данном предприятии возможно с помощью создания резервного фонда на покрытие непредвиденных расходов. Оно предусматривает установление соотношения между потенциальными рисками, изменяющими стоимость проекта, и размером расходов, связанных с преодолением нарушений в ходе его реализации.

Зарубежный опыт допускает увеличение стоимости проекта от 7 до $12 \%$ за счет резервирования на форс-мажор [15]. Казахстанские эксперты рекомендуют следующие нормы непредвиденных расходов, представленных в таблице 12 .

Таблица 12 - Рекомендуемые нормативы резервов на непредвиденные расходы Table 12 - Recommended ratios of provisions for contingencies

\begin{tabular}{|l|c|}
\hline \multicolumn{1}{|c|}{ Вид затрат } & $\begin{array}{c}\text { Изменение непредвиденных расходов, } \\
\%\end{array}$ \\
\hline Затраты/продолжительность работ казахстанских исполнителей & +20 \\
\hline Затраты/продолжительность работ иностранных исполнителей & +10 \\
\hline Увеличение прямых производственных затрат & +20 \\
\hline Снижение производства & -20 \\
\hline Увеличение процента за кредит & +20 \\
\hline Примечание - Источники [15],[16] & \\
\hline
\end{tabular}

Примечание - Источники [15], [16]

Кроме резервирования на форс-мажорные обстоятельства необходимо создание системы резервов на предприятии для оптимального управления денежными потоками. Речь идет о формировании резервного фонда, фонда погашения безнадежной дебиторской задолженности, поддержание оптимального уровня материальных запасов и нормативного остатка денежных средств и их эквивалентов.
Резервирование средств является, по сути, самострахованием предприятия. При этом следует иметь в виду, что страховые резервы во всех их формах хотя и позволяют быстро возместить понесенные потери, однако «замораживают» использование достаточно ощутимой суммы инвестиционных ресурсов. Повысить финансовую надежность проекта и финансовую устойчивость предприятия можно, предусмотрев реализацию следующих мероприятий по оптимизации структуры источников финансирования, а именно: 
- величины производственных запасов;

- незавершенного производства;

- запасов готовой продукции;

- уменьшение дебиторской задолженности;

- превышение кредиторской задолженности над дебиторской с целью покрытия недостатка оборотных средств;

- формирование финансовых резервов, позволяющих временно ослаблять финансовую напряженность;

- привлечение дополнительных кредитов на временное пополнение оборотных средств;

- увеличение прибыльности деятельности (снижение затрат);

- ускорение оборачиваемости средств.

Планирование указанных мероприятий потребует корректировки исходной информации, необходимой для расчетов эффективности проекта, и приведет к изменению не только финансовой надежности проекта, но и показателей экономической эффективности

\section{Заключение}

Результаты настоящей статьи и проведенное исследование по инновационному преобразованию вакуумного производства на предприятиях машиностроения на основе реализации нового инвестиционноинновационного проекта, позволило сделать следующие выводы:

1. Очевидно, что эффективность реализации инвестиционных проектов с инновационными составляющими влияет на организацию управления затратами и финансовый результат деятельности предприятия в целом. При этом эффективность управления затратами на производстве влияет на финансовую устойчивость предприятия, его ликвидность, платежеспособность, деловую активность и рентабельность. Выбор источника финансирования играет значительную роль при формировании обоснования эффективности проекта, который позволит увеличить прибыль предприятия и снизить затраты.

2. Для того чтобы окончательно принять управленческое решение о принятии проекта необходимо оценить как инвестиционный проект повлияет на финансовую устойчивость предприятия, на снижение затрат на производство и реализацию продукции предприятия, на котором он реализуется.

3. На основе показателей финансовохозяйственной деятельности АО «Востокмашзавод» можно констатировать, что анализ финансовой устойчивости показал, что коэффициент обеспеченности собственными сред- ствами с каждым годом становится ниже, что говорит о нехватке собственных средств в оборотном капитале. В целях обеспечения устойчивости собственных средств был предложен инвестиционный проект вакуумного производства продукции машиностроения, направленный на снижение затрат, через метод повышения технического уровня производства. Суть проекта заключается в покупке оборудования с помощью, которого предприятие внедрит в свое производство изготовление нового вида продукции (сварного ковша М 720-484).

4. Для обоснования принятия проекта на реализацию была проведена оценка его экономической и финансовой эффективности. На основании расчетов показателей экономической эффективности инвестиционного проекта, которые характеризуются положительными тенденциями развития деятельности предприятия. Срок окупаемости иинвестиционного проекта для инновационного преобразования вакуумного оборудования составит 3,5 года, при этом, ожидаемая доходность от реализации проекта прогнозируется на уровне $30,2 \%$ от общих вложенных финансовых средств. Следовательно, данный факт обеспечит достаточно высокую прибыльность инвестиционного проекта.

Внедрение инновационной продукции показало, что с помощью инновационного проекта АO «Востокмашзавод» улучшает деятельность в области качества и объема выпускаемой продукции, снижая затраты на производство, себестоимость производства, что позволяет инвестировать свободные денежные средства в перспективу развития и удержания устойчивости развития в условиях глобальных кризисов экономики. Улучшение финансовых результатов исследуемого объекта за счет нового проекта приведет к снижению рисков остановки производства, обеспечит увеличение производительности в условиях цифровой конкуренции, прибыльности проекта, доли собственного капитала предприятия и тем самым повышению его финансовой устойчивости.

\section{Список использованных источников}

1. Thurner, M., Glaune, P. (2020). Innovative Technologies for Market Leadership, 107-117.

2. Алексеев А.Н. (2014). Государственное регулирование инвестиционной деятельности в машиностроении России В сборнике: Инновационные технологии и экономика в машиностроении Сборник трудов V Международной 
научно-практической конференции. Томский политехнический университет, 97-101.

3. Празднов Г.С. (2017). Инновации в машиностроении: цель, проблемы, эффективность Креативная экономика, 11(12), 1389-1398. doi: $10.18334 /$ ce.11.12.38649

4. Тулеметова А.С., Жанакова Н.Н. (2019). Анализ основных тенденций развития машиностроения в мире и Казахстане. Экономика: стратегия и практика, 3(14), 99-112.

5. Пивоваров Р.А. (2017). Оценка эффективности инвестиционного проекта. Проблемы и перспективы экономики и управления: материалы VI Междунар. науч. конференции, 22-25. [Электронный pecypc]. URL: https://moluch.ru/ conf/econ/archive/263/13247/ (дата обращения: 08.12.2021)

6. Тимофеева Т.В., Снатенков А.А. (2007). Оценка инвестиционной привлекательности регионов РФ. Труды V Всероссийской конференции молодых ученых по институциональной экономике. Екатеринбург, 187-190.

7. Борисов В.Н., Почукаева О.В. (2013). Инновационное развитие машиностроения. Проблемы прогнозирования, 3, 38-51.

8. Борисов В.Н., Почукаева О.В. (2016). Эффективность инновационной и инвестиционной деятельности в машиностроении: методы оценки и измерения. Научные труды: Институт народнохозяйственного прогнозирования РАН, 3, 209-225.

9. Организация Объединенных Наций по промышленному развитию (ЮНИДО). [Электронный ресурс]. URL: https://dic.academic.ru/ dic.nsf/ruwiki/371045 (дата обращения: 08.12.2021)

10. Нурмухаметов Н.Н. (2021). Экономическая эффективность инновационного развития предприятия (на примере АО «УстьКаменогорский арматурный завод»). Вестник университета «Туран», 1(89), 23-30.

11. Матузова И. В. (2012). Методика оценки инновационного потенциала промышленного предприятия. Теоретическое обоснование стратегий инновационного развития промышленных предприятий. Вестник ЛГУ им. А. С. Пушкина, 3, 87-97.

12. Дубровина Н.А. (2021). Вестник Самарского университета. Экономика и управление, 12(1), $108-115$.

13. Отчет о финансово-хозяйственной деятельности АО «Востокмашзавод» за 2015-2020 гг

14. Кайгородцев А.А. (2004). Финансовый анализ деятельности предприятия: учебное пособие, 75-77.

15. Зимакова Л.А. (2005). Сборник задач по бухгалтерскому управленческому учету. М.: KpoKyc, 97-98.

16. Мальцева Ю.Н. (2017). Инвестиции: конспект лекций. [Электронный ресурс]. URL: https://econ.wikireading.ru/16232 (дата обращения: 08.12.2021)

17. Wee D., Kelly R., Cattell J., Breunig M. (2015). Industry 4.0 how to navigate digitization of the manufacturing sector. McKinsey Digital, 3-31.

\section{References}

1. Thurner, M., Glaune, P. (2020). Innovative Technologies for Market Leadership, 107-117.

2. Alekseyev, A.N. (2014). Gosudarstvennoye regulirovaniye investitsionnoy deyatel'nosti v mashinostroyenii Rossii V sbornike: Innovatsionnyye tekhnologii i ekonomika v mashinostroyenii Sbornik trudov V Mezhdunarodnoy nauchno-prakticheskoy konferentsii. Tomskiy politekhnicheskiy universitet, 97-101. (In Russ.)

3. Prazdnov, G.S. (2017). Innovatsii v mashinostroyenii: tsel', problemy, effektivnost' Kreativnaya ekonomika, 11(12), 1389-1398. doi: 10.18334/ce.11.12.38649 (In Russ.)

4. Tulemetova, A.S., Zhanakova, N.N. (2019). Analiz osnovnykh tendentsiy razvitiya mashinostroyeniya v mire i Kazakhstane. Ekonomika: strategiya i praktika, 3(14), 99-112. (In Russ.)

5. Pivovarov, R.A. (2017). Otsenka effektivnosti investitsionnogo proyekta. Problemy i perspektivy ekonomiki i upravleniya: materialy VI Mezhdunar. nauch. konferentsii, 22-25. [Electronic resourse]. URL: https://moluch.ru/conf/econ/archive/263/13247/ (date of access: 08.12.2021) (In Russ.)

6. Timofeyeva, T.V., Snatenkov, A.A. (2007). Otsenka investitsionnoy privlekatel'nosti regionov RF. Trudy VVserossiyskoy konferentsii molodykh uchenykh po institutsional'noy ekonomike. Yekaterinburg, 187190. (In Russ.)

7. Borisov, V.N., Pochukayeva, O.V. (2013). Innovatsionnoye razvitiye mashinostroyeniya. Problemy prognozirovaniya, 3, 38-51. (In Russ.)

8. Borisov, V.N., Pochukayeva, O.V. (2016). Effektivnost' innovatsionnoy i investitsionnoy deyatel'nosti v mashinostroyenii: metody otsenki i izmereniya. Nauchnyye trudy: Institut narodnokhozyaystvennogo prognozirovaniya RAN, 3, 209-225. (In Russ.)

9. Organizatsiya Ob"yedinennykh Natsiy po promyshlennomu razvitiyu (UNIDO). [Electronic resourse]. URL: https://dic.academic.ru/dic.nsf/ ruwiki/371045 (date of access: 08.12.2021)

10. Nurmukhametov, N.N. (2021). Ekonomicheskaya effektivnost' innovatsionnogo razvitiya predpriyatiya (na primere AO «Ust'Kamenogorskiy armaturnyy zavod»). Vestnik universiteta «Turan», 1(89), 23-30. (In Russ.)

11. Matuzova, I.V. (2012). Metodika otsenki innovatsionnogo potentsiala promyshlennogo predpriyatiya. Teoreticheskoye obosnovaniye strategiy innovatsionnogo razvitiya promyshlennykh predpriyatiy. Vestnik LGU im. A. S. Pushkina, 3, 87-97. (In Russ.)

12. Dubrovina, N.A. (2021). Vestnik Samarskogo universiteta. Ekonomika i upravleniye, 12(1), 108-115. (In Russ.)

13. Otchet o finansovo-khozyaystvennoy deyatel'nosti AO «Vostokmashzavod» za 2015-2020 gg. (In Russ.)

14. Kaygorodtsev, A.A. (2004). Finansovyy analiz deyatel'nosti predpriyatiya: uchebnoye posobiye, 75 77. (In Russ.) 
15. Zimakova, L.A. (2005). Sbornik zadach po bukhgalterskomu upravlencheskomu uchetu. M.: KroKus, 97-98. (In Russ.)

16. Mal'tseva YU.N. (2017). Investitsii: konspekt lektsiy. [Electronic resourse]. URL: https://econ. wikireading.ru/16232 (date of access: 08.12.2021)
17. Wee, D., Kelly, R., Cattell, J., Breunig, M. (2015). Industry 4.0 how to navigate digitization of the manufacturing sector. McKinsey Digital, 3-31.

\title{
Information about the authors
}

\begin{abstract}
* Nurbakhyt N. Nurmukhametov- Acting Professor of the Department of Management, NJSC L.N. Gumilyov Eurasian National University, Kazakhstan, e-mail: nyrbahit73@mail.ru, ORCID ID: https://orcid.org/ 0000- 0002$8551-0573$
\end{abstract}

Altyn B. Amerkhanova - Acting Associate Professor of the Department of Management, NJSC L.N. Gumilyov Eurasian National University, Kazakhstan, e-mail: a ab85@mail.ru, ORCID ID: https: //orcid.org/0000-0003-0465$272 X$

Karlygash T. Auezova - Acting Associate Professor of the Department of Management, NJSC L.N. Gumilyov Eurasian National University, Kazakhstan, e-mail: karlygash.auezova@mail.ru, ORCID ID: https://orcid.org/00000001-8774-3031

\section{Авторлар туралы мәліметтер}

* Нұрмұхаметов Н.Н. - Л.Н. Гумилев атындағы Еуразия ұлттық университеті КЕАҚ, менеджмент кафедрасының профессор м.а, Қазақстан, e-mail: nyrbahit73@mail.ru,ORCID ID: https://orcid.org/ 0000- 0002$8551-0573$

Амерханова А.Б. - «.Н. Гумилев атындағы Еуразия ұлттық университеті КЕАҚ, менеджмент кафедрасының доцентінін м.а., Қазақстан, e-mail: a_ab85@mail.ru, ORCID ID: https: //orcid.org/ 0000-0003-0465-272X

Ауезова К.Т. - Л.Н. Гумилев атындағы Еуразия ұлттық университеті КЕАҚ, менеджмент кафедрасының доцентінін м.а., Қазақстан, e-mail: karlygash.auezova@mail.ru, ORCID ID: https://orcid. org/0000-0001-87743031

\section{Сведения об авторах}

* Нурмухаметов Н.Н. - и.о. профессора кафедры «Менеджмент» НАО Евразийский национальный университет им. Л.Н. Гумилева, Казахстан, е-mail: nyrbahit73@mail.ru, ORCID ID: https://orcid.org/ 0000-00028551-0573

Амерханова А.Б. - и.о. доцента кафедры «Менеджмент», НАО Евразийский национальный университет им. Л.Н. Гумилева, Казахстан, e-mail: a_ab85@mail.ru, ORCID ID: https://orcid.org/0000-0003-0465-272X

Ауезова К.Т. - и.о. доцента кафедры «Менеджмент» НАО Евразийский национальный университет им. Л.Н. Гумилева, Казахстан, e-mail: karlygash.auezova@mail.ru, ORCID ID: https://orcid.org/0000-0001-8774-3031 